\title{
PROCESY OSADZONYCH W OBOZIE PRACY W POTULICACH PRZED SPECJALNYM SĄDEM KARNYM W TORUNIU (1944-1946)
}

\section{JUDICIAL PROCESS OF EMBEDDED IN A LABOR CAMP POTULICE BEFORE THE SPECIAL CRIMINAL COURT IN TORUN (1944-1946)}

\section{STRESZCZENIE}

Artykuł dotyczy procesów, jakie odbywały się w latach 1944-1945 przed Specjalnym Sądem Karnym w Toruniu. Omawia pokrótce powstanie zarówno Specjalnych Sądów Karnych, jak i Obozu Pracy w Potulicach. W treści opracowania autorka przedstawia, jak wyglą-

* Uniwersytet Mikołaja Kopernika w Toruniu. 
dały i czego dotyczyły procesy sądowe osób, które w tym czasie przebywały w Obozie Pracy w Potulicach. Praca powstała po przeanalizowaniu ok. 1200 akt znajdujących się w Instytucie Pamięci Narodowej w Bydgoszczy.

\section{Słowa kluczowe} cach.

Specjalne Sądy Karne, procesy sądowe, Obóz Pracy w Potuli-

\section{ABSTRACT}

This article study on the processes that took place in 1944-1945 before the Special Criminal Court in Torun. Briefly discusses the creation of both the Special Criminal Courts and Labor Camp in Potulice. The author presents how did this adjudicate looked like and what was the verdicts related to people who at that time were housed in a labor camp in Potulice. The work is the analysis of 1200 records located at the Institute of National Remembrance in Bydgoszcz.

\section{Keywords}

Special Criminal Courts, Litigation, Labor Camp in Potulice.

Okres II wojny światowej był koszmarem dla wielu narodów. Szczególne miejsce wśród pokrzywdzonych zajmują Polacy. Na skutek powszechnej potrzeby rozliczenia prawnokarnego skutków wojny i okupacji powojenna polityka karna zmierzała do znalezienia takich środków karnych, które dałyby możliwość szybkiego skazania prześladowców. Pierwszym wśród licznych aktów prawnych o znaczeniu politycznym był dekret z 31 sierpnia 1944 r. o wymiarze kary dla faszystowsko-hitlerowskich zbrodniarzy winnych zabójstw i znęcania się nad ludnością cywilną i jeńcami oraz dla zdrajców Narodu Polskiego ${ }^{1}$. Akt ten

1 Dekret z dnia 31 VIII 1944 r. o wymiarze kary dla faszystowsko-hitlerowskich zbrodniarzy winnych zabójstw oraz znęcania się nad ludnością cywilną i jeńcami oraz dla zdrajców Narodu Polskiego (Dz.U. Nr 4, poz. 16; tekst jedn. Dz.U. z 1946 r. Nr 69, poz. 377). 
przewidywał surową karalność licznych form prześladowania ludności cywilnej i jeńców wojennych. Wiele z osób posądzonych o współpracę z okupantem, jak i jeńców wojennych po II wojnie światowej postanowiono osadzić w obozach pracy ulokowanych na terenie całego kraju.

Obozy pracy w Polsce powstały na mocy instrukcji kierownika Resortu Bezpieczeństwa Publicznego Stanisława Radkiewicza z 30 października 1944 r. $^{2}$ oraz dekretu rządu z 28 czerwca 1946 r. $^{3}$ Powojenne ustawodawstwo dotyczące osób osadzonych w obozach charakteryzowała duża niespójność, a procedury karne były bardzo przewlekłe. Kwestie odnoszące się do tzw. zdrajców narodu oraz tzw. odstępstwa od narodowości obrazują ten problem bardzo znamiennie. Po wojnie większość osób, które podpisały niemiecką listę narodowościową (Deutsche Volksliste), była poddawana procesowi tzw. rehabilitacji, czyli przywracania obywatelstwa polskiego. Z podobną sytuacją mamy do czynienia w przypadku tzw. weryfikacji, czyli przyznawania obywatelstwa polskiego byłym obywatelom III Rzeszy (Reichsdeutschom), uznawanym za Polaków. Osoby, które nie poddały się procesowi rehabilitacji bądź weryfikacji, lub uznane zostały przez aparat bezpieczeństwa lub władze administracyjne za Niemców, mogły trafić do obozów pracy

Instrukcja kierownika Resortu Bezpieczeństwa Publicznego PKWN z dnia 30 października 1944 r. wydana dwa miesiące po ogłoszeniu dekretu sierpniowego, zawierała definicję „zdrajcy narodu” oraz nakazywała osadzenie „na czas nieoznaczony w miejscu odosobnienia" jako karę za ten czyn. Instrukcja była

2 AAN, PKWN, I/80, Instrukcja Kierownika Resortu Bezpieczeństwa Publicznego PKWN o przytrzymaniu i odesłaniu do obozów pracy zdrajców narodu tzw. volksdeutschów [w oryginale wielką literą i z błędem „Volksdeutsche"], 30 X 1944 r., s. 3-4. Cyt. za: B. Kopka, Podstawy prawne i organizacyjne funkcjonowania powojennych obozów pracy $w$ dokumentach Ministerstwa Bezpieczeństwa Publicznego, [w:] Obóz w Potulicach - aspekt trudnego sąsiedztwa polsko-niemieckiego $w$ okresie dwóch totalitaryzmów, pod red. A. Paczoskiej, Bydgoszcz 2005, s. 41.

3 Dekret z dnia 28 VI 1946 r. o odpowiedzialności karnej za odstępstwo od narodowości w czasie wojny 1939-1945 (Dz.U. Nr 41, poz. 237).

4 B. Kopka, Podstawy prawne i organizacyjne..., s. 41. 
adresowana do wojewódzkich, powiatowych i miejskich komendantów Urzędów Bezpieczeństwa Publicznego oraz milicji. Milicja Obywatelska oraz rady narodowe jako czynnik społeczny miały za zadanie wspierać w działaniach Resort Bezpieczeństwa Publicznego. Zgodnie z treścią Instrukcji każdy przedwojenny obywatel polski, który w czasie okupacji zadeklarował swą przynależność do narodu niemieckiego lub wskazał swoje niemieckie pochodzenie, był zdrajcą narodu. Zgodnie z tą definicją, każdy obywatel II Rzeczypospolitej narodowości niemieckiej był uznawany za zdrajcę. Urzędy Bezpieczeństwa wraz z milicją miały zatrzymać i odesłać do obozów wszystkich volksdeutschów, którzy ukończyli 16 lat. Członkowie ich rodzin, nawet jeśli nigdy nie deklarowali związków z narodem niemieckim, miały otrzymać w dokumentach adnotację „Rodzina volksdeutscha" 5 . Instrukcja była w zasadzie zbiorem szykan, jakim mieli zostać poddani Niemcy, wcześniej będący obywatelami polskimi. Ostatni punkt nadaje dokumentowi namiastkę legalizmu, stanowiąc, że ostateczna decyzja o osadzeniu „przytrzymanych” na czas nieoznaczony w miejscu odosobnienia oraz o konfiskacie majątku tychże osób, jak i ich rodzin, należy do kompetencji prokuratora specjalnego sądu karnego i samego sądu.

Powstanie Specjalnego Sądu Karnego zainicjowane zostało zapowiedzią Krajowej Rady Narodowej w lutym 1944 r., że „żaden niemiecki zbrodniarz wojenny, żaden zdrajca narodu nie może ujść kary". Nowa władza od samego początku rozpoczęła działania w kierunku ustanowienia specjalnych przepisów prawa karnego, określających dość precyzyjnie rodzaje przestępstw wojennych oraz stworzenia specjalnego sądownictwa do rozpoznawania spraw karnych z tej kategorii ${ }^{6}$.

5 Warto w tym miejscu zaznaczyć, że na terenie samego Pomorza Gdańskiego w związku ze stosowanym w latach 1942-1944 przymusem germanizacyjnym duża grupa ludności została wpisana na niemiecką listę narodową. Około 60\% ludności tego regionu wpisało się do III grupy listy. Cyt. za: L. Chrzanowski, Wypędzenia z Pomorza, „Biuletyn Instytutu Pamięci Narodowej" 2004, nr 5 (40), s. 34-48.

6 J. Sawicki, T. Cyprian, Prawo polskie $w$ walce z hitleryzmem i kolaboracjonizmem, „Demokratyczny Przegląd Prawniczy” 1946, nr 11-12. 
Najważniejszym, a zarazem pierwszym aktem prawa karnego był dekret z 31 sierpnia 1944 r. o wymiarze kary dla faszystowsko-hitlerowskich zbrodniarzy winnych zabójstw oraz znęcania się nad ludnością cywilną i jeńcami oraz dla zdrajców narodu polskiego. Jak pisał Jerzy Sawicki, „prawo sądów specjalnych ma zaspokoić potrzebę odpłaty. [...] Tylko represja w formie czystej zemsty mogła uspokoić wzburzone społeczeństwo. Stąd dla niektórych stanów faktycznych przewidziana jest tylko jedna absolutna kara śmierci" ". Kara śmierci przewidziana w tym akcie była sankcją bezwzględnie określoną i połączoną z przepadkiem całego mienia, a przewidziana była za udział w dokonywaniu zabójstw oraz denuncjacje. Dekret umożliwiał m.in. ukaranie osób biorących udział „w organizacji przestępczej, powołanej lub uznanej przez władze państwa niemieckiego lub z nim sprzymierzonego (NSDAP, SA, SS i inne). Dekret przewidziane w nim przestępstwa oddawał właściwości specjalnych sądów karnych. Sposób tworzenia sądów, ich działania i postępowanie przed rzeczonym sądem uregulowano dekretem z 12 września 1944 r. o specjalnych sądach karnych dla spraw zbrodniarzy faszystowsko-hitlerowskich ${ }^{8}$. W 1944 r. przy trzech sądach apelacyjnych utworzono pierwsze sądy karne, a w miarę uwalniania kraju od wojsk niemieckich tworzono kolejne. Dekret zakładał istnienie jednego sądu specjalnego na każdy okręg apelacji. W praktyce powstało ich dziewięć w dziesięciu okręgach apelacyjnych (Gdańsk, Katowice, Kraków, Lublin, Poznań, Rzeszów, Toruń, Warszawa - z tymczasową siedzibą w Łodzi, Wrocław; jedynie okręg apelacyjny w Olsztynie nie miał specjalnego sądu karnego) ${ }^{9}$. Zgodnie $\mathrm{z}$ regulacjami zawartymi $\mathrm{w}$ dekrecie $\mathrm{w}$ sprawach podlegających właściwości specjalnego sądu karnego prowadzono dochodzenie. Wyeliminowało to istniejącą do tej pory instytucję sędziego śledczego, w którego kompetencji było prowadzenie śledztwa, a całe postępowanie przygotowawcze złożono na ręce prokuratora. Prokurator zgod-

7 J. Sawicki, O prawie sądów specjalnych, [w:] Wymiar sprawiedliwości w odrodzonej Polsce - 22 VII 1944-22 VII 1945, Warszawa 1945, s. 55-64.

8 Dz.U. $1944 \mathrm{Nr} 4$, poz. 21.

9 A. Lityński, Historia prawa Polski Ludowej, Warszawa 2010, s. 55. 
nie z powyższymi uregulowaniami mógł zadecydować o przeprowadzeniu dochodzenia samemu bądź za pośrednictwem organów bezpieczeństwa publicznego. W praktyce przesłuchania świadków przeprowadzane przez Urząd Bezpieczeństwa były nacechowane skrajnym subiektywizmem i pytaniami sugestywnymi, w wielu przypadkach prokurator zlecał przeprowadzić je ponownie sędziom śledczym bądź sędziom sądów grodzkich. Tymczasowe aresztowanie stosowano obligatoryjnie na podstawie zarządzenia prokuratora. Całe postępowanie od wszczęcia dochodzenia aż do złożenia w sądzie aktu oskarżenia miało być bardzo szybkie, co, jak się okazuje na podstawie przeanalizowanych akt Specjalnego Sądu Karnego w Toruniu, nie zawsze się udawało ${ }^{10}$. Akt oskarżenia nie wymagał uzasadnienia. Orzeczenia zapadały na rozprawie i wydawane były w składzie jednego sędziego i dwóch ławników. Udział obrońcy był obowiązkowy, ale tylko na rozprawie głównej. Postępowanie było jednoinstancyjne, a wyrok ostateczny i prawomocny. Skazanemu na karę śmierci przysługiwało prawo wniesienia prośby o ułaskawienie do Przewodniczącego Krajowej Rady Narodowej.

Wśród akt spraw, w których Specjalny Sąd Karny w Toruniu wyrokował, ok. 10\% (wśród 1294 teczek znajduje się 130 akt spraw zakończonych wyrokami) ${ }^{11}$ dotyczy osób umieszczonych w obozach pracy. Byli to ludzie osadzeni w obozie pracy w Potu-

10 Przykładem może tu być sprawa IPN By Paula Schlenhardt, w której to informacja od obozu pracy do Prokuratury o osadzeniu wpłynęła nie w sierpniu 1945 r., a dopiero w lutym 1946 r. Prokuratura podjęła pierwszą czynność w sprawie, jaką było nakazanie Urzędowi Bezpieczeństwa przeprowadzenia dochodzenia. W marcu 1946 r. wydano akt oskarżenia, a pierwsza rozprawa, którą odroczono z powodu niedoprowadzenia oskarżonego, odbyła się 20 IX 1946 r. Rozprawę odroczono z tej samej przyczyny jeszcze raz. Ostatecznie w związku z likwidacją Specjalnego Sądu Karnego sprawę rozpoznał na posiedzeniu Sąd Okręgowy w Bydgoszczy w dniu 30 VI 1947 r. Podejrzany do czasu wydania wyroku uniewinniającego spędził sześć miesięcy w obozie pracy i niespełna rok i 3 miesiące $\mathrm{w}$ areszcie śledczym.

11 Pośród akt dotyczących osób osadzonych w obozach pracy tylko 5 spraw na 130 dotyczyło kobiet. W trzech wypadkach orzeczono karę śmierci za znęcanie się nad ludnością polską poprzez bicie gumową pałką bądź kijem. W ogromnej większości przypadków (ok. 75\%) zapadały wyroki uniewinniające. 
licach i jego oddziałach. Wiąże się to z właściwością miejscową spraw rozpoznawanych przez ten sąd. Przestępstwa popełnione na obszarze danego Sądu Specjalnego miały być przez niego rozpoznawane.

Tworzenie obozów pracy było powodowane chęcią odizolowania od społeczeństwa polskiego ludności niemieckiej przy jednoczesnej możliwości kontrolowania jej i wykorzystywania jako taniej siły roboczej. Z początkiem 1945 r., a więc krótko po wyzwoleniu, w szybkim tempie zaczęto organizować obozy i miejsca odosobnienia dla Niemców i volksdeutschów. Początkowo tworzyli i nadzorowali je sami Rosjanie, stopniowo oddając nadzór nad nimi milicji oraz Urzędowi Bezpieczeństwa. Często były to przypadkowe miejsca, jak stodoły, szopy, baraki. Istniały krótko, bo tylko do czasu przekazania osadzonych tam osób do właściwych obozów. Najczęściej wykorzystywano do tych celów obozy stworzone przez Niemców, jak w przypadku obozu w Potulicach, który stał się największym obozem pracy dla Niemców na Pomorzu Gdańskim. Obóz w Potulicach z czasem przemianowano na Centralny Obóz Pracy Potulice (COPP) i ustanowiono przy nim Pomorski Zarząd Obozów Pracy, którego zadaniem miało być sprawowanie zarządu nad wszystkimi obozami województwa pomorskiego, zachodniopomorskiego i gdańskiego ${ }^{12}$. W aktach Toruńskiego Specjalnego Sądu znajdują się sprawy osób osadzonych w obozach pracy: Potulice oraz w jego oddziałach tj. Toruń-Rudak, Mielęcin, Świecie, Łęgnowo, Złotów, Barcin-Wapienno. Sporadycznie osadzeni trafiali tam także po wydaniu przez Sąd Specjalny wyroku skazującego, jak i uniewinniającego, co wskazywało na chęć jak najefektywniejszego wykorzystania „wrogów narodu” w celu odbudowy kraju ${ }^{13}$.

12 S. Jankowiak, Aparat bezpieczeństwa wobec ludności niemieckiej na Pomorzu w latach 1945-1947, [w:] Obóz w Potulicach..., s. 34-35.

13 IPN By 686/514 akta sprawy Erny Endel. Specjalny sąd karny w wyroku uniewinniającym napisał „z zastrzeżeniem, że osk. podlega obozowi pracy przymusowej". Świadczy to, że osoby narodowości niemieckiej mogły być również skierowane do obozów pracy przez specjalny sąd karny, jeśli sąd uznał, że należy ich odizolować od społeczeństwa polskiego. W późniejszych wyrokach uniewinniających sąd zaznaczał, że oskarżonego należy zwolnić lub 
Dochodzenia w sprawach osób osadzonych w obozach pracy zaczynały się w różny sposób. W pierwszym okresie istnienia Specjalnego Sądu Karnego Urząd Bezpieczeństwa rozpoczynał je po uzyskaniu donosu ustnego bądź pisemnego. Przykładem może być sprawa Grzegorza Zytura, który trafił do obozu i został osądzony na skutek donosu złożonego na MO przez czterech mieszkańców jego rodzinnej wsi. We wniosku o ukaranie piszą: „Niżej podpisani prosimy o zatrzymanie w Obozie Pracy volksdeuthera G. Zybura z Kruszwicy na podstawie poniższego uzasadnienia [...] Pkt 4. G. Zytur był szpiclem na rzecz Niemiec. Przysyłany był specjalnie do kościoła katolickiego na mszę św. celem stwierdzenia, czy się tam uprawia politykę polską [...] z powyższego wynika, że Zytur był szkodnikiem Państwa Polskiego"14.

Duża część spraw miała swój początek podczas przesłuchań i aresztowań prowadzonych przez Urząd Bezpieczeństwa. Zaczynały się one zawiadomieniem z Centralnego Obozu Pracy w Potulicach do Prokuratury Specjalnego Sądu Karnego z informacją o dokonanym przez Urząd transporcie nowych więźniów i załączoną do tego listą osób podejrzanych o przynależność do antypolskich organizacji. Prokurator co do każdej osoby z listy wystosowywał pismo do Milicji Obywatelskiej z poleceniem przesłuchania podejrzanego na okoliczność: gdzie przebywał w czasie wojny, czy był wpisany do którejś z grup narodowej listy niemieckiej, czy należał do SS oraz nakazywał sprawdzić „czy jest tatuowany znakami »SS « (należy zbadać tę okoliczność szczególnie pod lewym ramieniem)"15. Między innymi tak rozpoczęło się dochodzenie w sprawie Karla Aeckla obywatela Czechosłowacji. Przesłuchanie zostało przeprowadzone przez wywiadowcę śledczego z Posterunku Milicji Obywatelskiej w Barcinie ${ }^{16}$. Podejrzany zeznał: „w czasie okupacji od roku

oddać w ręce Urzędu Bezpieczeństwa, co często było jednoznaczne z ponownym osadzeniem w obozie.

14 IPN By 686/142 akta sprawy Grzegorza Zytura.

15 IPN By 686/936 akta sprawy Karla Ackela.

16 Milicja ustaliła, że podejrzany został oddelegowany do oddziału Potulic w Wapiennie. Komenda Powiatowa w Bydgoszczy nakazała Posterunkowi w Barcinie przesłuchanie podejrzanego. 
1939 do 1941 przebywałem przy rodzicach w Staliz (Czechosłowacja) [...]. Do organizacji Hitlerjugend byłem wzięty przymusowo w 1940, stamtąd w roku 1943 do wojska niemieckiego do jednostki »SS«. Na froncie byłem we Francji w okolicach Paryża. Do niewoli wzięto mnie w okolicach Strasund przez armię radziecką". Podejrzany został osadzony do czasu przeprowadzenia rozprawy $\mathrm{w}$ więzieniu $\mathrm{w}$ Inowrocławiu. W akcie oskarżenia zarzucono mu przynależność do SS. Podczas rozprawy, która odbyła się na sesji wyjazdowej w Inowrocławiu, Sąd opierając się tylko na zeznaniach oskarżonego, wydał wyrok uniewinniający. W uzasadnieniu wyroku Sąd zaznaczył, że „oskarżony wbrew swej woli i bez starań w trybie zaciągu wojskowego został włączony do formacji „SS Waffen”, oraz że nie miał on możności uniknąć tego obowiązku” oraz „W danym wypadku brak cech przestępstwa $\mathrm{z}$ art. $1 \S 2$ omawianego dekretu". Więzienie w Inowrocławiu przesłało do Sądu zawiadomienie o zwolnieniu więźnia i „odstawieniu do P.U.B.P. w Inowrocławiu”17. Około połowa omawianych przypadków miała podobne początki, tj. oskarżenie o przynależność do SS i w związku z nieuznaniem przez Specjalny Sąd Karny formacji „SS Waffen” za tożsamą z SS, kończyła się wyrokiem uniewinniającym.

Wartym zaznaczenia jest fakt, że Urząd Bezpieczeństwa czasem nie stosował się do nakazów aresztowania wydanych przez prokuratora Specjalnego Sądu Karnego. Zgodnie z wydanym nakazem aresztowania, jak i nakazem przyjęcia do aresztu osoba podejrzana od momentu wszczęcia dochodzenia powinna przebywać w areszcie. Zdarzało się jednak, że podejrzani umierali w trakcie dochodzenia, a w akcie zgonu jako miejsce zejścia wpisywano obóz pracy, w którym zgodnie z dyspozycjami podejrzany nie powinien się znajdować ${ }^{18}$. Również samo wykonywanie zarządzeń zawartych w wyrokach pozostawiało wiele do życzenia. Znakomicie obrazuje to przypadek Karola Frisa, który 7 X 1945 r. jako osadzony w obozie pracy w Milęcinie był

17 IPN By 686/936 akta sprawy Karla Ackela.

18 Przykładowo: IPN By 686/1194 akta sprawy Henryka Bader, który zmarł w obozie pracy w Potulicach ponad cztery miesiące czasu po wydaniu nakazu aresztowania, a miesiąc czasu po wydaniu aktu oskarżenia. 
przesłuchiwany przez Sędziego Sądu Grodzkiego, a następnie, już po wszczęciu dochodzenia, przez Urząd Bezpieczeństwa. Akt oskarżenia został wydany 26 III 1946 r. Dnia 8 V 1946 r. na posiedzeniu niejawnym sprawę umorzono, ponieważ Więzienie Karno-Śledcze we Włocławku po dopatrzeniu się, że oskarżony już został wcześniej skazany na 3 lata więzienia przez Specjalny Sąd Karny dnia 14 XII 1945 r., wysłało zapytanie do Sądu z prośbą o wyjaśnienie, czy przeciwko tej samej osobie odbędzie się ponownie rozprawa ${ }^{19}$.

W późniejszym okresie, czyli od około października 1945 r. do obozów jeździli na przesłuchania osadzonych sędziowie sądów grodzkich. Zeznania spisywane przez nich były zwięzłe, rzeczowe i pozbawione cech subiektywizmu, jaki towarzyszył przesłuchaniom prowadzonym przez Urząd Bezpieczeństwa. Jeżeli w trakcie przesłuchania okazało się, że w zachowaniu podejrzanego podczas wojny są znamiona przestępstwa $\mathrm{z}$ dekretu sierpniowego, sędzia odręcznie pisał na protokole przesłuchań decyzję o zwolnieniu z obozu pracy, przekazaniu do dyspozycji prokuratora Specjalnego Sądu Karnego i o osadzeniu $\mathrm{w}$ areszcie ${ }^{20}$.

Przełomem w kwestii przesłuchań stało się zeznanie uzyskane od Richarda Mullera, który za czasów wojny pracował jako sanitariusz w szpitalu miejskim w Ratenau. Zeznał: „pracując w szpitalu, miałem możność zauważyć, że wszyscy członkowie formacyj SS mają wytatuowaną grupę krwi pod ręką/pod pachą/[...]. Natomiast żołnierze innych formacyj grupę krwi mieli uwidocznioną na tabliczkach miedzianych rozpoznawczych. [...] Było 4 grupy krwi oznaczone: 0, AB, A i B"21. Sędziowie sądów grodzkich oraz funkcjonariusze Milicji Obywatelskiej podczas przesłuchań w obozach pracy poddawali osadzonych oględzinom zewnętrznym ciała, mającym wykazać posiada-

19 IPN By 686/1004 akta sprawy Karola Frisa.

20 Przykładowo: IPN By 686/504 akta sprawy Ernesta Furstenwalda. Sędzia Sądu Grodzkiego na protokole przesłuchania podejrzanego odręcznie pisze czerwonym flamastrem: „decyzja o: wydaniu nakazu aresztowania, przyjęcia do więzienia i zwolnienie z obozu".

21 IPN By 686/976 akta sprawy Karola Reitmaiera. 
nie tatuaży. Osoby, u których znajdywano takowe, oskarżano początkowo o przynależność do SS, a w efekcie rozpraw, na których okazywało się, że nie należeli do tejże formacji, a do Waffen SS (co było zgodne z ich zeznaniami z okresu dochodzenia),oskarżano o samą przynależność do Waffen SS. Byli to jeńcy wojenni pochodzenia m.in. rumuńskiego, czechosłowackiego, jugosłowiańskiego, których przymusowo zaciągnięto do wojska niemieckiego. Dochodzenia na szerszą skalę w sprawie tych osób w zasadzie nie prowadzono z uwagi na brak osób pokrzywdzonych, mogących zeznawać na ich niekorzyść. Jedynym dowodem załączonym do aktu oskarżenia było rzeczone zeznanie sanitariusza, które jak się później okazało, było niezgodne z prawdą, gdyż Niemcy nie tylko tatuowali członków formacji SS, ale również osoby zaciągnięte do służby wojskowej ${ }^{22}$. Specjalny Sąd Karny w każdej z takich spraw uniewinniał oskarżonych, których zeznaniom dawał wiarę ${ }^{23}$. W uzasadnieniu wyroków argumentował, że „należenie do oddziałów wojskowych, tzw. Waffen SS nie stanowi cech przestępstwa z dekretu z dnia 31 VIII 1944 r., była to bowiem organizacja czysto wojskowa, a właściwie część składowa armii niemieckiej, niemająca specjalnych celów politycznych, jak pokrewna jej organizacja t.zw. Schutzstaffen der N.S.D.A.P." ${ }^{24}$.

Ogromna większość osób skazanych spośród osadzonych w obozie pracy $\mathrm{w}$ Potulicach i jego oddziałach odpowiadała z art. 1 § 2 dekretu P.K.W.N. z 31VIII 1944 r. (Dz.U. Nr. 4, poz. 16) w brzmieniu po nowelizacji z 16 II 1945 r. (Dz.U. Nr. 7, poz. 29.), który stanowił: „Kto, idąc na rękę władzy okupacyjnej niemieckiej, działał lub działa w inny sposób na szkodę Państwa Polskiego albo osób wśród ludności cywilnej lub jeńców wojennych, podlega karze 3 więzienia do lat 15, lecz na czas nie krótszy od 3 lat lub dożywotnio albo karze śmierci". Głównie

22 Wynika to z zeznań osób, które przynależały do Waffen SS, z zeznań znajdujących się w aktach Specjalnego Sądu Karnego wynika, że tatuaże w oddziałach wojskowych pojawiły się u schyłku wojny.

23 Wśród akt osób osadzonych w obozach pracy jest to znaczący odsetek spraw zakończonych uniewinnieniem - ok. 50\%.

24 IPN 686/976 akta sprawy Karola Reitmaiera. 
były to osoby oskarżone o przynależność do formacji SA oraz NSDAP, a epizodycznie zdarzały się przypadki osądzenia osoby za SS czy Selbschutz. Wymierzano im karę 3 lub 5 lat więzienia z okresem pozbawienia praw obywatelskich i honorowych na czas od 3 do 5 lat oraz obligatoryjnie konfiskatę całego majątku. Dekret nie dawał możliwości wymierzenia łagodniejszej kary.

Ważną cechą Specjalnego Sądu Karnego było sądzenie na sesjach wyjazdowych, poza siedzibą sądu macierzystego. Decyzje w sprawie prowadzenia spraw podejmowano wcześniej, podczas posiedzeń niejawnych, w których brał udział prokurator. Ustalano na nich linię postępowania i politykę karną. Rozprawy prowadzone na sesjach wyjazdowych cieszyły się ogromnym zainteresowaniem społeczności lokalnej, łatwiejszy był w nich udział świadków i ławników. Często dopiero w dniu rozprawy zgłaszali się nowi świadkowie, zarówno oskarżenia, jak i obrony mający często istotny wpływ na wynik sprawy. Rudolf Kawczak, prezes Sądu Specjalnego w Katowicach, argumentował to słowami: „sądy specjalne z istoty swego charakteru powinny być rozpoznawane $\mathrm{w}$ miejscu dokonania przestępstw, w przeciwnym razie tracą swój właściwy sens i zadanie"25.

Zakończenie działań wojennych i przebieg pierwszej fali procesów spowodował, że status sądownictwa specjalnego zaczął wywoływać zastrzeżenia wśród prawników. Krytykowano zbytnią surowość przepisów, które w warunkach pokoju okazały się zbyt drastyczne ${ }^{26}$. Zarzucano też dekretowi, że ujęte w nim normy prawne okazały się zbyt sztywne, a w niektórych przypadkach sędziowie zgłaszali problemy w orzekaniu zgodnie z przepisami, ze względu na specjalne okoliczności dotyczące sądzonego ${ }^{27}$. Dnia 17 X 1946 r. ogłoszono dekret o zniesieniu Specjalnych Sądów Karnych, a ich właściwość przekazano od

25 AAN, Ministerstwo Sprawiedliwości, 7592, Sprawozdanie z działalności SSK w Katowicach, 4 II 1946 r. Cyt. za: Z. Biegański, Powojenne procesy członków załóg Niemieckich Obozów Przymusowych i Obozów Pracy na Pomorzu Gdańskim i Kujawach, [w:] Obóz w Potulicach..., s. 48.

${ }_{26}$ W. Barcikowski, Najważniejsze zagadnienia ustawodawstwa, „Demokratyczny Przegląd Prawniczy" 1946, nr 1, 2.

27 A. Landau, C. Wasilkowski, Odpowiedzialność za zbrodnie czasu wojny w prawie polskim, „Demokratyczny Przegląd Prawniczy” 1946, nr 11, 12. 
17 X 1946 r. sądom powszechnym orzekającym w składzie ławniczym $^{28}$. Sprawami oskarżonych, pociągniętych do odpowiedzialności na mocy przepisów zawartych w dekrecie sierpniowym zajmowały się po 1 I 1947 r. sądy okręgowe. Niedokończone sprawy Specjalnego Sądu Karnego w Toruniu przejął Sąd Okręgowy w Bydgoszczy.

\section{BIBLIOGRAFIA}

Barcikowski W., Najważniejsze zagadnienia ustawodawstwa, „Demokratyczny Przegląd Prawniczy" 1946, nr 1, 2.

Biegański Z., Powojenne procesy członków załóg Niemieckich Obozów Przymusowych i Obozów Pracy na Pomorzu Gdańskim i Kujawach, [w:] Obóz w Potulicach - aspekt trudnego sasiedztwa polsko-niemieckiego w okresie dwóch totalitaryzmów, pod red. A. Paczoskiej, Bydgoszcz 2005.

Chrzanowski L., Wypędzenia z Pomorza, „Biuletyn Instytutu Pamięci Narodowej" 2004, nr 5 (40), ss. 34-48.

Jankowiak S., Aparat bezpieczeństwa wobec ludności niemieckiej na Pomorzu w latach 1945-1947, [w:] Obóz w Potulicach - aspekt trudnego sasiedztwa polsko-niemieckiego $w$ okresie dwóch totalitaryzmów, pod red. A. Paczoskiej, Bydgoszcz 2005.

Kopka B., Podstawy prawne i organizacyjne funkcjonowania powojennych obozów pracy $w$ dokumentach Ministerstwa Bezpieczeństwa Publicznego, [w:] Obóz w Potulicach - aspekt trudnego sąsiedztwa polsko-niemieckiego $w$ okresie dwóch totalitaryzmów, pod red. A. Paczoskiej, Bydgoszcz 2005.

Landau A., Wasilkowski C., Odpowiedzialność za zbrodnie czasu wojny w prawie polskim, „Demokratyczny Przegląd Prawniczy” 1946, nr 11, 12.

Lityński A., Historia prawa Polski Ludowej, Warszawa 2010.

Sawicki J., Cyprian T., Prawo polskie w walce z hitleryzmem i kolaboracjonizmem, „Demokratyczny Przegląd Prawniczy” 1946, nr 11-12.

Sawicki J., O prawie sądów specjalnych, [w:] Wymiar sprawiedliwości w odrodzonej Polsce - 22 VII 1944-22 VII 1945, Warszawa 1945.

\section{Kontakt e-mail:}

ewamariarosa@wp.pl. 